\title{
Decomposition of Factors Associated With Housing Material Inequality in Under-Five Deaths in Low and Middle-Income Countries
}

Oyewale Mayowa Morakinyo ( $\nabla$ omorakinyo@cartafrica.org )

University of Ibadan https://orcid.org/0000-0001-5289-9378

Adeniyi Francis Fagbamigbe

University of Ibadan

Ayo Stephen Adebowale

University of Ibadann

\section{Research}

Keywords: Under-five deaths, Housing material inequality, Low-and middle-income countries

Posted Date: January 26th, 2021

DOl: https://doi.org/10.21203/rs.3.rs-152523/v1

License: (c) (i) This work is licensed under a Creative Commons Attribution 4.0 International License.

Read Full License

Version of Record: A version of this preprint was published at Archives of Public Health on January 4th, 2022. See the published version at https://doi.org/10.1186/s13690-021-00768-0. 


\section{Deaths in Low and Middle-income Countries}

3

4

5

6

7

8

9

*Oyewale Mayowa Morakinyo

Department of Environmental Health Sciences, Faculty of Public Health, College of Medicine, University of Ibadan, Nigeria

omorakinyo@cartafrica.org

Adeniyi Francis Fagbamigbe

Department of Epidemiology and Medical Statistics, Faculty of Public Health, College of Medicine, University of Ibadan, Nigeria

fiadeniji@cartafrica.org

Ayo Stephen Adebowale

Department of Epidemiology and Medical Statistics, Faculty of Public Health, College of Medicine, University of Ibadan, Nigeria

adehamilt2008@yahoo.com

*Corresponding author: omorakinyo@ cartafrica.org 


\section{Abstract}

2 Background: Low-and Medium-Income Countries (LMIC) continue to record high burden of 3 under-five deaths (U5D). There is a gap in knowledge of the factors contributing to housing 4 materials inequalities in U5D. This study examined the contributions of the individual- and 5 neighbourhood-level factors to housing materials inequalities in influencing U5D in LMIC.

6 Methods: We pooled data from the most recent Demographic and Health Surveys for 56 LMIC 7 conducted between 2010 and 2018. In all, we analysed the data of 798,796 children living in 859,791 neighbourhoods. The outcome variable was U5D among live births within 0 to 59 9 months of birth. The main determinate variable was housing material types, categorised as unimproved housing materials (UHM) and improved housing materials (IHM) while the individual-level and neighbourhood-level factors are the independent variables. Data were analysed using Fairlie decomposition analysis at $\alpha=0.05$.

Results: The overall U5D rate was 53 per 1000 children, 61 among children from houses built with UHM, and 41 among children from houses built with IHM $(\mathrm{p}<0.001)$. This rate was higher among children from houses that were built with UHM in all countries except in Malawi, Zambia, Lesotho, Gambia, Liberia, Sierra Leone, Indonesia, Maldives, Jordan, and Albania.

None of these countries had significant pro-IHM inequality. The factors explaining housing inequalities in U5D include household wealth status, residence location, source of drinking water, media access, paternal employment, birth interval, and toilet type.

Conclusions: There are variations in individual- and neighbourhood-level factors driving housing materials inequalities as it influences U5D in LMIC. Interventions focusing on reducing the burden of U5D in households built with UHM are urgently needed. 
2 The implementation of the adopted international framework of the United Nations Convention on the Rights of the Child and other global interventions including the Global Strategy for Women's, Children's and Adolescent's Health, the Millennium Development Goals, and the Sustainable Development Goals (SDGs) (1) by the global community, have led to a significant reduction in childhood deaths worldwide. Globally, there has been a decline in under-five deaths (U5D) from 93 deaths per 1000 live births in 1990 to 38 deaths per 1000 live births in 2019 (2). A reduction in U5D by more than two-thirds were recorded in more than 80 countries inclusive of 31 Low- and lower-middle-income countries in 2019 (LMIC) (3).

Despite these achieved level of U5D reduction worldwide, U5D remains unacceptably high across certain countries and regions of the world (Figure 1) (4). Some of these countries are found in Africa, Asia and to some extent in Latin America. Countries with the highest U5D include the Democratic Republic of Congo, Ethiopia, India, Nigeria, and Pakistan (2,3). In 2019, 5.2 million children under age five died globally representing 14,000 deaths daily (5). More than half of these deaths occurred in sub-Saharan Africa. The under-five mortality rate was 41 deaths per 1000 live births in LMIC as compared to 5 deaths per 1000 live births in high-income countries in 2019 (3).

Studies have shown that infectious diseases, including acute respiratory infections, measles, malaria and diarrhoea are leading direct causes of U5D, while the indirect causes are most especially the socio-economic, environmental and behavioural factors (6). Difficulties associated with accessing fundamental lifesaving care such as the skill of birth attendant, postnatal care, adequate dietary intake, and vaccinations against common childhood diseases also predispose children to the risk of dying before the age of five years. Other factors that have been linked with U5D include the child gender, weight at birth, birth interval, and birth order, 
1 multiple births, maternal education, maternal age, marital status, maternal and paternal occupation, sex of the head of the household, access to media, sources of drinking water, toilet type, type of cooking fuel, household wealth index, place of residence and the type of housing materials with which a house is built $(2,7)$. The wellbeing of household occupants is also a

5 reflection of the building materials with which the house is built $(8,9)$.

6 Children's homes are a key determinant of their environment (10). It is also one of the major determining factors in their health outcome (11). Poor housing conditions are one of the ways through which social and environmental inequalities lead to health inequality (11). Poor housing conditions can elicit a range of diseases including respiratory infections, mental and behavioural dysfunction and neurological disorders which impact negatively on children's health (12). It is also a risk factor for U5D. Previous study have established the fact that the probability of a child dying before the age of 5 years was likely to be higher among children who lived in houses built with unimproved materials than those living in houses built with improved materials (9).

Literature is replete that inequality exists in the proportion of U5D and housing type (9). However, there is a gap in the literature on what factors contributes to this inequality. Understanding these factors that contribute to housing materials inequalities in USD can provide useful information needed to further reduce the burden of U5D in LMIC. This study is therefore designed to identify and quantify the contributions of the factors that determine the inequalities in U5D among children from houses built with improved housing materials and unimproved housing materials. 


\section{$1 \quad$ Methods}

\section{Study design and data}

3 Data for this cross-sectional study were obtained from ICF, the primary owner and implementer 4 of Demographic and Health Surveys (DHS) across countries worldwide. These surveys are nationally representative household surveys conducted in LMIC. This study used data from 56 recent DHS conducted between 2010 and 2018 and available in the public domain as at $15^{\text {th }}$ of September 2020 when the data were harvested from dhsprogram.com. The DHS uses a multistage, clustered and stratified sampling design with households as the sampling frame using an individual country's most recent census as a sampling frame. Typically, the upper stages include states or districts, or regions depending on country-specific administrative nomenclatures. The last stage of the multi-stage sampling is the selection of clusters from which households are selected. The clusters are referred to as the primary sampling units (PSUs) (13,14). All eligible women (aged 15 to 49 years) and men (aged 15-65 years) within each sampled household were interviewed. The surveys were not self-weighting. Therefore, sampling weights were calculated for all participants to account for unequal selection probabilities as well as for non-response. The application of the sampling weights ensures that survey findings represent the full target population. The DHS data include household data, women's data, birth recode data and children recode data and men's data. However, the present study made use of the children recode data. Further details of the sampling methodologies are available at dhsprogram.com. In all, we pooled the data of 798,796 children, living in 59,791 neighbourhoods nested within 56 countries.

\section{Outcome variable}

The outcome variable in this study is under-five death (U5D). Under-5 deaths is death among live births within the first five years of life. It is defined as all deaths within 0 to 59 months of birth (ICF International Inc., 2012; Kenya National Bureau of Statistics \& ICF International, 
1 2015; National Population Commission (NPC)[Nigeria] \& ICF International, 2019). To ensure

2 the completeness and correctness of this variable, mothers were asked to name all their

3 livebirths within five years preceding the date of the study. They were then asked if each of

4 those children were alive or dead. The dates of death, the ages at death for the dead children

5 and survival status were then used to determine U5D. Under-5 death was coded as a

6 dichotomous variable: Alive or Died before $5^{\text {th }}$ birthday.

\section{$7 \quad$ Main determinant variable}

8 The main determinate variable is the quality of the materials used to build houses where 9 children under 5 years of age live. It was derived from the three sub-variables. These are the materials used for the house floor, wall and roof. During the survey, the enumerators personally observed these housing materials. The DHS provided a guideline for the classification of materials used for any of these three parts of the house as either improved or not. The classifications are (i) the improved floor materials are cement, ceramic tiles, vinyl asphalt strips, parquet and polished wood while the unimproved floor materials are earth, sand, dung, rudimentary, wood planks, palm, bamboo, and others; (ii) the improved wall materials include cement, stone with lime/cement, cement blocks and bricks while the unimproved wall materials are no wall, cane/palm/trunks, dirt, rudimentary, bamboo with mud, stone with mud, uncovered adobe, plywood, and others (iii) the improved roof materials are cement and roofing shingles while the unimproved materials consist of no roof, thatch/palm leaf, sod, rudimentary, rustic mat, palm/bamboo, wood planks, cardboard, wood, and others (15-18). Each of the improved floor, wall and roof materials were scored "1" while unimproved materials were scored "0". We then summed these scores. Houses with $>=2$ scores out of the maximum obtainable 3 scores were classified as houses built with improved housing materials (IHM) while houses with $<2$ scores were categorized as houses built with unimproved housing materials (UHM). 


\section{Independent variables}

2 The independent variables consist of individual-level and neighbourhood-level factors

3 identified in the literature to be associated with childhood deaths.

\section{$4 \quad$ Individual-level factors}

5 The children characteristics, mothers' characteristics and the households' characteristics

6 constitute the individual-level factors. The children characteristics are sex (male, female),

7 weight at birth (average+, small and very small), birth interval (firstborn, $<36$ months and $>=36$

8 months) and birth order (1, 2, 3 and 4+), a child is a twin (single, multiple (2+). The maternal

9 characteristics: maternal education (none, primary or secondary plus), maternal age (15 to 24 ,

25 to 34,35 to 49 ), marital status (never, currently and formerly married), maternal and paternal

employment status (working or not working), health insurance (yes /no). The household

characteristics include the sex of the head of the household (male or female), access to media (at least one of radio, television, or newspaper), sources of drinking water (improved or unimproved), toilet type (improved or unimproved), cooking fuel (clean fuel or biomass), housing materials (improved or unimproved) and household wealth index (poorest, poorer, middle, richer and richest), place of residence (rural or urban).

Neighbourhood-level factors

Neighbourhood was operationalized as the clustering of children. The DHS uses "clusters" as the PSU. People of the same cluster are very likely to share similar contextual factors $(13,14)$. We regard children as "neighbours" if they belong to the same cluster. In this study, we computed neighbourhood socioeconomic status (SES) as a neighbourhood-level from the proportion of mothers within the same clusters without education, belonging to a household in two lowest wealth quintiles, no media access and unemployed using the principal component factor method. 


\section{Statistical analyses}

2 The analytical approach for this study included descriptive statistics, bivariable analysis and

3 multivariable decomposition analysis. Descriptive statistics to show the distribution of the

4 children's background characteristics as well as the distribution of USD among the children

5 from houses with IHM and UHM by countries and characteristics. The bivariable analysis was

6 conducted using the Z-test to determine the equality of proportions of USD among the children

7 from houses with IHM and UHM within each country and region (Table 1). Charts were used

8 for visualization. The spatial distribution of under-five deaths per 1000 livebirths among

9 children in houses with improved and unimproved housing materials are shown in Figure 1.

10 The maps were built in Microsoft Projects 2020.

We calculated the risk differences (RD) in U5D among the children from houses with IHM and UHM. A risk difference greater than 0 suggests that U5D are higher among the children from houses built with UHM than those from IHM (pro-unimproved housing material). Conversely, a negative RD indicates under-5 deaths are higher among the children from houses with IHM than those from UHM (pro-improved housing material). We carried out country-level metaanalysis of the prevalence of U5D in each of the countries by computing the risk difference in the development of U5D between U5C from houses with improved and unimproved housing materials and presented the results in Figure 2. A random-effects meta-analysis was used on the assumption that each country is estimating a study-specific true effect. We implemented the meta-analysis in R software by specifying the summary measure (SM) as risk difference (RD), the number of deaths in houses with improved and unimproved housing materials as well as the numbers of participants for each country, grouped by regions using the "metabin" command in R. We built a 95\% confidence interval (CI) around the RDs to determine their significance. 
1 The Mantel-Haenszel (MH) Odds Ratio (OR) and tests of heterogeneity of ORs were conducted

2 to ascertain that the countries are different with regards to the odds ratio of USD among children from houses with IHM and UHM and a test of homogeneity of ORs among all the countries with a significant odds ratio of USD to determine if the odds of having USD death in those countries are homogenous. Finally, the Fairlie decomposition analysis (FDA) techniques using logistic models was applied.

Sampling weights were applied in all the analysis in this study to adjust for unequal cluster sizes, stratifications and to ensure that our findings adequately represent the target population. Multicollinearity among the independent variables was tested using the "colin" command in Stata version 16. The command provided the variance inflation factor (VIF). The VIF is an approximate of $1 /\left(1-R^{2}\right)$ ranging from 1 to infinity. The $R^{2}$-value is obtained by regressing $\mathrm{t} j^{\text {th }}$ independent variable on other independent variables. All variables with VIF $>2.5$ were removed from the regression analysis. Literature has shown concerns about VIF >2.5 (19).

The FDA technique is an offshoot of the well-known Blinder-Oaxaca decomposition analysis technique that was originally developed for linear models (20-22). FDA was developed following the inefficiency of the Blinder-Oaxaca decomposition analysis technique in handling non-linear outcomes such as logit or probit models (23-27). The FDA was developed for nonlinear regression models and used in the quantification of the contributions to differences in the prediction of an outcome of interest between two groups (28). This technique is a counterfactual method with an assumption that "what the probability of under-5 death would be if children from houses built with UHM had the same characteristics as the children whose houses are built with IHM?".

The FDA allows for the decomposition of the difference in an outcome variable between 2 groups (children from houses with IHM and UHM) into 2 components. The first component is 
1 the "explained" (also referred to as the "compositional" or "endowments") portion of that gap

2 that captures differences in the distributions of the measurable characteristics. The explained

3 part is the portion of the gap in USD attributable to the differences in observable, measurable

4 characteristics between children from houses with IHM and UHM. This method helps to

5 quantify how much of the gap between the children from houses with UHM and the children

6 from houses with IHM is attributable to these differences in specific measurable characteristics.

7 The second component of the model is the "unexplained" (also referred to as the "structural"

8 component or the "coefficient") part. The unexplained part is the portion of the gap due to the

9 differences in the estimated regression coefficients and the unmeasured variables between the

10 two groups.

11 The Fairlie decomposition technique works by constraining the predicted probability between

120 and 1 as available in a logit model. The coefficients $(\beta)$ estimated by the logit regression

13 technique with the probability of under-5 deaths conditioned on the independent variables $(X)$

14 is obtained as

$$
\operatorname{Pr}(U 5 D=1 \mid X)=\frac{e^{X^{\prime} \beta}}{1+e^{X^{\prime} \beta}} \ldots \ldots \ldots \ldots \ldots
$$

We carried out an FDA analysis by calculating the difference between the predicted probability for Group A (children from houses with UHM) using the Group B (children from houses with UHM) regression coefficients and the predicted probability for under-5 deaths among Group B using its regression coefficients (24).

Fairlie et al. showed that the decomposition for a nonlinear equation $Y=F(X)$, can be expressed as: 


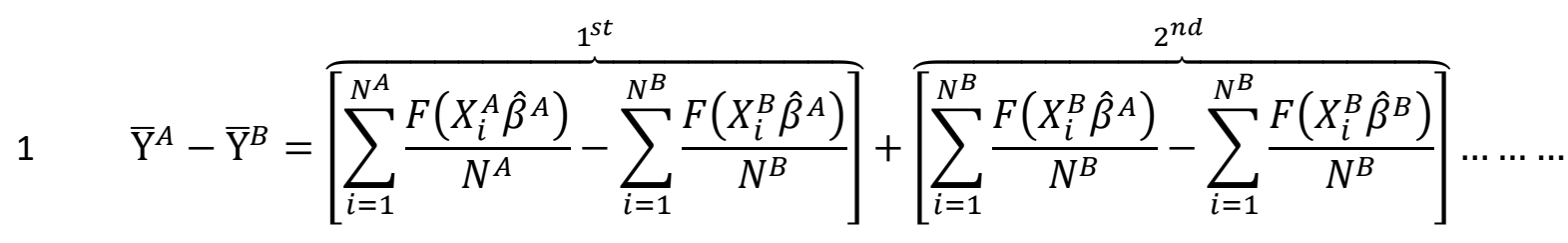

2 Where $N^{A}$ is the sample size for group $J$ (29). In equation (1), $\overline{\mathrm{Y}}$ is not necessarily the same as

$3 F(\overline{\mathrm{X}} \hat{\beta})$, unlike in BODA where $F\left(X_{i} \beta\right)=X_{i} \beta$. The 1st term (explained) is the part of the gap

4 in the binary outcome variable that is due to group differences in distributions of $X$, and the

5 2nd term (unexplained) is the part due to differences in the group processes determining levels

6 of $Y$ (under-5 deaths). The 2 nd term also captures the portion of the binary outcome variable

7 gap due to group differences in unmeasurable or unobserved endowments.

8 The estimation of the total contribution is the difference between the average values of the

9 predicted probabilities. Using coefficient estimates from a logit regression model for a pooled sample, $\hat{\beta}^{*}$, the independent contribution of $X_{1}$ and $X_{2}$ to the group, the gap can be written as

$$
\frac{1}{N^{B}} \times \sum_{i=1}^{N^{B}} F\left(\hat{\alpha}^{*}+X_{1 i}^{A} \hat{\beta}_{1}^{*}+X_{2 i}^{A} \hat{\beta}_{2}^{*}\right)-F\left(\hat{\alpha}^{*}+X_{1 i}^{B} \hat{\beta}_{1}^{*}+X_{2 i}^{A} \hat{\beta}_{2}^{*}\right)
$$

and

$$
\frac{1}{N^{B}} \times \sum_{i=1}^{N^{B}} F\left(\hat{\alpha}^{*}+X_{1 i}^{B} \hat{\beta}_{1}^{*}+X_{2 i}^{A} \hat{\beta}_{2}^{*}\right)-F\left(\hat{\alpha}^{*}+X_{1 i}^{B} \hat{\beta}_{1}^{*}+X_{2 i}^{B} \hat{\beta}_{2}^{*}\right)
$$

respectively. The contribution of each variable to the gap is thus equal to the change in the average predicted probability from replacing the group $B$ distribution with the group $A$ distribution of that variable while holding other variables constant. Other detailed numerical of this approach have been reported in the literature $(24,25,27,29,30)$. We implemented the FDA in STATA 16 (StataCorp, College Station, Texas, United States of America) using the "Fairlie" command. 


\section{$1 \quad$ Results}

2 Table 1 shows the distribution of U5D across children from houses built with UHM and IHM

3 by countries and regions. The overall prevalence of houses with UHM was $58.8 \%$. The highest

4 proportion of children from houses built with UHM was found in Papua New Guinea (99.2\%)

5 and least in Albania at 2.4\%. The overall weighted prevalence of U5D was 53 per 1000

6 children, 61 among children from houses built with UHM and 41 among children from houses

7 built with IHM $(\mathrm{p}<0.001)$. The prevalence of U5D among children from houses built with

8 UHM ranged from 3 per 1000 children in Albania to 120 in Nigeria, while it ranged from 4 in

9 Albania to 119 in Sierra Leone among children from houses built with IHM. The z-test of equality of prevalence among children from houses built with UHM and IHM was statistically significant $(\mathrm{p}<0.05)$ in Afghanistan, Angola, Bangladesh, Benin, Burkina Faso, Burundi, Cambodia, Cameroon, Congo DR, Cote d'Ivoire, Dominican Rep, Ethiopia, Guatemala, Guinea, India, Kenya, Mali, Mozambique, Myanmar, Niger, Nigeria, Pakistan, Peru, Senegal, South Africa, Timor Leste, and Togo. The spatial distribution of U5D per 1000 livebirths among children in houses with improved housing materials are shown in Figure 2(a) and 2(b) respectively.

Table 2 shows the descriptive statistics of the characteristics of the children across the 56 LMIC and prevalence of U5D by the quality of housing materials. The overall U5D was highest among multiple births compared with singletons (20.3\% vs 5.6\%). These rates were $23.3 \%$ vs 5.6\% among children from houses built with UHM and $15.8 \%$ vs 3.8\% among children from houses built with IHM. Also, the prevalence of U5D was highest among females than males (59.2\% vs 58.5\%), among children using unimproved water sources (80.8\%) and unimproved toilets $(77.1 \%)$. 


\section{Risk Differences in U5D among children from UHM and IHM}

2 The risk differences of U5D among children from houses built with UHM and IHM across the countries studied are presented in Figures 3, 4 and 5. A meta-analysis of the prevalence of U5D among children from houses built with UHM and IHM in each of the countries was carried out and presented the results in Figure 3. The prevalence of U5D was generally higher (RD>0) among children from houses built with UHM in all the countries (pro-UHM inequality) except in Malawi, Zambia, Lesotho, Gambia, Liberia, Sierra Leone, Indonesia, Maldives, Jordan and Albania with $\mathrm{RD}<0$. None of these countries had significant pro-IHM inequality. The heterogeneity of the RDs was $88 \%(\mathrm{p}<0.01)$.

Irrespective of regions, the fixed effects of pro-UHM differences in U5D were largest in Nigeria (46.5/1000 children) while the fixed effects of pro-IHM RD were largest for Lesotho (-9.9/1000). The random effect, which is the RD of U5D irrespective of country of residence was $11.8 / 1000$ children (95\% CI: 8.4-15.3). The greatest contribution to the weight of the random effect was found in India at $2.3 \%$ while the least was in Papua New Guinea at $0.6 \%$ as shown in Figure 3.

\section{Risk difference and prevalence of under-5 deaths and magnitude of housing material inequality}

In Figures 4 and 5, we used red and orange colours to depict the countries with significant proUHM inequality and insignificant inequality respectively. There was no statistically significant pro-IHM inequality in any of the countries. Figures 4 and 5 showed that four of the nine countries in Eastern Africa, three of the six countries in Middle Africa, only South Africa in Southern Africa and nine of the 13 countries in West Africa, four of the seven countries in Southern Asia and three countries in the Caribbean showed statistically significant pro-UHM inequality. No country in South-Eastern Asia and Oceania, one country each in Central Asia, 
1 Western Asia, Central America, and South America showed statistically significant pro-UHM

2 inequality (Figures 3, 4 and 5).

\section{Relationship between the prevalence of U5D and magnitude of inequality}

4 The relationships between the prevalence of U5D and the magnitude of the inequality by the differences in the houses, where the children's lives were built of improved or unimproved materials in the 56 countries involved in this study, are presented in Figure 4. We categorised the countries into four distinct categories based on their prevalence of U5D and sizes of the inequalities in each country: (i) High U5D and high pro-UHM inequality countries such as Cote D'Ivoire, Nigeria, Mali, Niger and Burkina Faso (ii) High U5D and high pro-IHM inequality countries such as Sierra Leone, Liberia and Lesotho (iii) Low U5D and high proUHM inequality countries such as Dominican Republic, India, Cambodia, and South Africa (iv) Low U5D and high pro-IHM inequality countries such as Jordan and Gamb

Decomposition of factors in the prevalence of U5D by inequalities in the improvement of housing materials

The Mantel-Haenszel (MH) pooled estimate of the odds ratio (OR) of having U5D controlling for the countries of the children. We estimated MH-OR $=1.33$ (95\% CI: 1.30-1.36) and tested a null hypothesis: $\mathrm{OR}=1$; and obtained $\mathrm{z}=23.8(\mathrm{p}<0.001)$ and (ii) Test of heterogeneity: $X^{2}=$ 207.3, degree of freedom (d.f.) $=55(\mathrm{p}<0.001)$, I-squared (variation in odds ratio $(\mathrm{OR})$ attributable to heterogeneity) $=73.5 \%$. Of the 56 countries, statistically significant pro-UHM was found in only 26 countries. The countries are Afghanistan $(p=0.001)$, Angola $(p<0.0001)$, Bangladesh $(p=0.010)$, Benin $(p=0.001)$, Burkina Faso $(p<0.0001)$, Burundi $(p=0.005)$, Cambodia ( $\mathrm{p}<0.0001)$, Cameroon $(\mathrm{p}=0.048)$, Congo DR $(\mathrm{p}=0.001)$, Cote d'Ivoire $(\mathrm{p}=0.010)$, Dominican Rep $(p<0.0001)$, Ethiopia $(p=0.000)$, Guatemala $(p<0.0001)$, Guinea $(p<0.0001)$, 
$1(p=0.004)$, Nigeria $(p<0.0001)$, Pakistan $(p<0.0001)$, Peru $(p<0.0001)$, Senegal $(p<0.0001)$,

2 South Africa $(\mathrm{p}<0.0001)$, Timor Leste $(\mathrm{p}<0.0001)$, and Togo $(\mathrm{p}=0.005)$.

3 The test of homogeneity of the odds of U5D among the children from the pro-UHM countries

4 showed that ORs: $X^{2}=95.10$, d.f. $=25$, and $\mathrm{p}=0.001$. We then computed the Mantel-Haenszel

5 pooled estimate of the odds ratio (OR) of having U5D among the children in the 26 countries

6 with pro-UHM inequalities while controlling for the countries. We had MH-OR=1.42 (95\%

7 CI: $1.38-1.46)$.

8 The 26 LMIC with pro-U5H inequality in U5D were included in the Fairlie decomposition 9 analysis. Figure 6 shows the detailed decomposition of the part of the pro-UHM inequality caused by compositional and structural effects of the factors associated with U5D. The red boxes in the heat map are the "explained" (compositional component) while the "unexplained" (structural component) portions of the pro-UHM inequalities are depicted in blue boxes as shown in Figure 5. The lighter the red colour, the lower the percentage contribution of the "explained" portion and the lighter the blue colour, the lower the percentage contribution of the "unexplained" portion.

We found wide variations in the factors associated with the pro-U5H inequalities across the countries. There was clustering among household wealth status, residence location, source of drinking water, media access, paternal employment, birth interval and toilet type while maternal education, neighbourhood SES, birth order and cooking fuel formed another cluster. All these factors contributed mostly to the inequalities. Also, Ethiopia, Bangladesh, Cameroun, Afghanistan and Niger formed a cluster of countries with similar associated factors with U5D while India, Congo DR, Cambodia and Cote d'Ivoire formed another cluster.

Different factors had the largest association with U5D in different countries. In Ethiopia, the greatest contributions to pro-UHM equalities are household wealth status (1728\% - 17 times 
1 higher odds of death among children from the richest household compared with those from

2 poorest households), residence location (752\%), drinking water sources (450\%), maternal education (307\%) and cooking fuel (135\%). Neighbourhood SES (236\%), household wealth status (288\%), cooking fuel (233\%), media access (201\%) and residence location (174\%) contributed most to pro-UHM in Bangladesh. In Cote d'Ivoire, the largest contributions to proUHM inequality in U5D were household wealth status (132\%), residence location (119\%), and neighbourhood SES (99\%).

\section{Discussions}

This study identified factors that contributed to housing material inequality in U5D in 56 LMIC, on which limited research has previously been conducted. The most salient findings show that (1) higher prevalence of U5D was recorded among children living in houses built with UHM in 46 out of 56 countries studied (2) there was no statistically significant pro-IHM inequality in any of the countries but significant pro-UHM was recorded in only 26 countries (3) factors associated with the pro-UHM and pro-IHM inequalities in U5D differ widely across countries.

The highest U5D was recorded among twin births compared with singletons. The rates were $23.3 \%$ vs $5.6 \%$ among children from houses built with UHM and $15.8 \%$ vs $3.8 \%$ among children from houses built with IHM. A startling one-fifth of twins died before attaining age 5 years in sub-Saharan Africa. The risk of dying is three times higher among multiple births compared to singletons (31). The rate of U5D is two to five times higher among twin birth compared to singletons in regions known for low childhood deaths (31) and in sub-Saharan countries where the highest global U5D has been observed in the recent times $(32,33)$. There is a higher probability of U5D among twins than singletons in households sourcing water from unimproved sources. Since twins start complimentary food much earlier than singletons, the use of unimproved water in the preparation of complementary foods could contaminate such 
1 foods with gastroenteritis which are risk factors for communicable diseases and malnutrition

2 (34,35). This may explain the higher U5D recorded among twin births. Our study showed evidence of higher U5D among children from households with unimproved water sources and unimproved toilet. Drinking water from unimproved sources and the use of unimproved toilet make children more vulnerable to diarrhoea, parasitic and helminthic infections which may compromise their nutritional status and make them susceptible to poor health outcomes (36$38)$.

Moreover, the proportion of pro-UHM inequality (99.2\%) was highest in Papua New Guinea (PNG) and least in Albania (2.4\%). Papua New Guinea is a low resource, and socioeconomically diverse country $(39,40)$ with the majority of the people occupying the low socio-economic cadre and thus cannot access quality and affordable housing $(41,42)$. Although, PNG has the highest number of houses built with UHM, it did not translate to high U5D in the country. This might be unconnected with the non-existence of reliable data to measure childhood mortality in PNG. PNG relies mostly on the use of civil registration and routine health data which have been reported to be incomplete, deficient and inaccurate for measuring childhood mortality in the country (43).

Findings from this study show that Nigeria has the highest rate of U5D among children from houses with UHM. This result gave credence to the study by Adebowale et al. who investigated if housing materials were a predictor of U5D in Nigeria using the DHS 2013 dataset (9). They reported that the hazard of U5D was 1.46 higher among children who lived in houses with UHM than those in IHM. The refined U5D estimates in houses with UHM and IHM was 143.5 and 90.8 per 1000 live births, respectively (9). Living in houses built with unimproved materials can predispose children to a range of health morbidities that culminate in deaths. For 
1 instance, the odds of malaria infection was significantly higher among under-five children who

2 lived in houses built completely with unimproved materials than those living in improved

3 housing materials in Nigeria (18). In 2018, children under-5 years made up 67\% (272 000) of

4 global malaria deaths. Nigeria accounted for $24 \%$ of all malaria global deaths (44). In another

5 study conducted among under-five children in Nigeria, more cases (65.2\%) than controls

6 (42.4\%) who were diagnosed with respiratory infections lived in houses of poor quality (45).

7 Pneumonia, a form of acute respiratory infection, is one of the highest causes of U5D in Nigeria

8 killing more than 140,000 annually (46).

9 The RD in U5D between houses built with UHM and those built with IHM was obvious across 10 countries. Forty-six countries recorded higher U5D (RD>0) in houses with pro-UHM inequality than the ten countries with pro-IHM inequality $(\mathrm{RD}<0)$. In the regions, statistically significant pro-UHM inequality in U5D was found in four Eastern countries (Burundi, Ethiopia, Kenya, Mozambique), nine Western African countries (Benin, Burkina Faso, Cote D'Ivoire, Guinea, Mali, Niger, Nigeria, Senegal, Togo), four Southern Asian counties (Afghanistan, Bangladesh, India, Indonesia), three in Caribbean countries (Dominican, Myanmar, Timor-Leste). Countries in South-Eastern Asia (Cambodia, Philippines), Oceania (Papua New Guinea), Central Asia (Kyrgyz Rep, Tajikistan), Western Asia (Armenia, Yemen, Jordan), Central America (Honduras), and South America (Peru) had no statistically significant pro-UHM inequality. An RD of 12 per 1000 children observed among countries with significant pro-UHM inequality suggests that more deaths will be recorded among children whose mothers lived in houses with UHM than those from houses with IHM. One probable reason for the differences in the housing materials inequalities can be attributed to countrylevel factors which cut across individual, household and neighbourhood factors and varies across LMIC (47-49). There is the need for urgent intervention in LMIC by the government and relevant stakeholders through the provision of low-cost and sustainable housing, and the 
1 enforcement or initiation of policies and programmes that encourage the maintenance of

2 existing housing units.

3

4 Moreover, our findings show the relationship between the prevalence of U5D and the 5 magnitude of housing material inequality. Countries such as Maldives, Armenia, Jordan and 6 Albania have USD of less than 25 per 1000 births which were what the SDG is targeting. The

7 WHO had reported an $80 \%$ reduction in the prevalence of U5D in Eastern and South-Eastern

8 Asia countries (50). This achievement was attributed to the political will of the government of 9 these countries to implement primary health care and universal health coverage through improved access to quality care, free health services for mothers and children, family planning support and capacity building of health workers (50).

However, countries such as Nigeria, Mali, Niger, Burkina Faso and Guinea have high U5D and high-risk differences between children living in houses from UHM and IHM. A weak health system, political and economic instability among other factors that prevent mothers and their children from accessing quality lifesaving healthcare services have been identified as the cause of high U5D in Cote D'Ivoire, Nigeria, Mali, Niger and Burkina Faso. Countries such as Nigeria, Mali, Niger, Burkina Faso and Guinea should learn from other countries (Maldives, Armenia, Jordan and Albania) with low U5D and low-risk differences between living in houses from UHM and IHM, by taking urgent steps towards the realization of target 3.2 of the SDGs. It is interesting to note that there was no statistically significant pro-IHM inequality in any of the countries. This further shows the link between good housing quality and improved health and wellbeing of its inhabitants $(8,9,51)$. 
1 We found wide variations in the factors explaining the housing material differentials in the

2 prevalence of U5D in LMIC. Children from households with poor wealth quintile, who resides

3 in rural areas, drink water from unimproved sources, uses unimproved toilet types, have poor

4 access to media, have short birth interval and fathers that are unemployed have a higher

5 probability of having pro-UHM inequality in experiencing U5D. These findings are consistent

6 with previous studies $(7,52,53)$.

7

8 An individual choice of housing type, features, size and quality are dependent on several factors

9 including socio-economic factors (54). In LMIC, households with poor wealth quintile have

10 limited choices and are more likely to live in houses built with inferior materials, and have less

to spend on maintenance and repairs $(54,55)$ which invariably increases the likelihood of child death. The outcome of lengthy non-maintenance of buildings includes dilapidated structures, leaking ceiling and pipes, peeling off of paints and cracks and holes in walls and floors. Cracks on walls and floors provide a conducive environment for mites, respiratory viruses and cockroaches to breed; all of which elicit respiratory morbidity $(9,51,56)$. Also, housing disrepair can act as stressors thus compromising the human immune system (54).

Moreover, poverty is also a predictor of unclean fuel use in LMIC $(57,58)$. When unclean fuel is burnt, it releases harmful pollutants such as respirable particulate matter and carbon monoxide into the atmosphere (59). A child's exposure to fumes from unclean fuel can suppress the functioning of the immune system while increasing bronchial reactivity, which promotes susceptibility to bacterial and viral pathogens $(60,61)$. Respiratory infections from unclean fuel is a major cause of deaths among children $(59,62)$. 
1 Nonetheless, the use of unimproved toilet facilities hinders safer disposal of faeces and

2 promotes the risk of contact between diarrhoea causative organism and human host (Aziz et

3 al., 2018). Diarrhoea is a major cause of U5D in LMICs (63-65). Conversely, having an

4 educated mother, living in a neighbourhood of high SES, high birth order and cooking with

5 clean fuel reduces the probability of U5D and influenced the housing material inequalities in

6 U5D across LMIC. This position has been reported in the literature $(66,67)$.

7 We found wide variations across countries in the factors associated with the pro-under five 8 housing inequalities. The highest contributors to pro-UHM equalities in Ethiopia are household 9 wealth status, residence location, drinking water sources, maternal education and cooking fuel. 10 Neighbourhood SES, household wealth status, cooking fuel, media access and residence location contributed most to pro-UHM in Bangladesh while in Cote d'Ivoire, the largest contributions to pro-UHM inequality in U5D were household wealth status, residence location, and neighbourhood SES. The findings from our study bring to the fore the importance of enhancing the compositional and structural factors if housing materials inequalities in U5D are to be reduced. Integrated geographically specific interventions may be a better approach to tackling the housing materials inequalities in U5D in LMIC with policies and programmes tailored to country-specific needs.

\section{Study strengths and limitations}

This study is one of the first to demystify the factors associated with housing materials inequality in LMIC. The representative nature of data from 59 DHS, their large sample size and high response rate makes the quality of findings from the study useful for international comparison. The causal relationship between housing materials and U5D could not be determined because of the cross-sectional nature of this study. Also, the measure of child mortality using information obtained from mothers may underestimate the actual rate as a result 
1 of recall bias. The Fairlie decomposition analysis used in this study has some advantages over

2 the Blinder-Oaxaca decomposition analysis technique in handling non-linear outcomes such as

3 logit or probit model. It can effectively handle non-linear regression models and quantification

4 of the contributions to an outcome of interest between two groups.

5

\section{Conclusions}

7 In this study, we identified a high prevalence of U5D with significant pro-unimproved housing 8 materials inequalities in most LMIC. This showed that the burden of U5D, which is 9 disproportionately higher among children living in houses built with unimproved housing materials compared to those in houses built with improved materialswas explained by the individual, household and community-level factors. The decomposition analysis revealed that factors such as wealth quintile, place of residence, drinking water sources, toilet types, media access, birth interval and paternal employment are the major contributors to housing inequalities in most LMIC. These findings can serve as a spur for planning children's countryspecific survival programs. Interventions targeted towards the use of good quality materials for the construction of houses and their subsequent maintenance can help reduce the burden of U5D and other related health morbidities, and thus, ensures the wellbeing of their inhabitants.

Abbreviations

CI: Confidence Interval;

DHS: Demographic and Health Survey; FDA: Fairlie Decomposition Analysis IRB: Institutional Review Board; LMIC: Low- And Middle-Income Countries; PSU: Primary Sample Unit; RD: Risk Difference; 
1 PNG: Papua New Guinea;

2 U5C: Under-Five Children;

3 U5D: Under-five deaths

4 Under-5 Deaths: Under-five deaths

5 UNICEF: United Nations International Children's Emergency Fund;

6 WHO: World Health Organization;

7

\section{Declarations}

\section{$9 \quad$ Ethics approval and consent to participate}

We analysed secondary data collected originally by ICF in conjunction with the participating countries. ICF had received ethical approval to conduct the study from the Institutional Review Board (IRB) of ICF Macro at Fairfax, Virginia in the USA. IRB reviewed and approved the MEASURE DHS Project Phase III. IRB in the USA. ICF granted us access and permission to use the data. There were no need for further ethical approvals. DHS Program has remained consistent with confidentiality and informed consent over the years. ICF ensures compliance with the U.S. Department of Health and Human Services regulations for the respect of human subjects. No further approval was required for this study. Further documentations on ethical issues relating to the surveys are available at dhsprogram.com

\section{Consent for publication}

Not applicable.

\section{Availability of data and materials}

The datasets generated and/or analysed during the current study are available in the DHS repository, http://dhsprogram.com with Accession number 140625.

\section{Competing interests}

The authors declare that they have no competing interests. 


\section{$1 \quad$ Funding}

2 The authors received no funding for this study.

3

\section{Authors' contributions}

$5 \mathrm{OMM}$ and AFF conceptualised and designed the study. AFF curated and analysed the data and provided the visualizations. OMM did the literature search and discussions. ASA contributed to the background, methods, and discussion sections. All authors (AFF, OMM and AAS) contributed to data interpretation and writing of the manuscript. All authors have read and approved the manuscript.

Acknowledgements

The authors are grateful to ICF Macro, USA, for granting the authors the request to use the

DHS data.

\section{References}

1. UNICEF. Convention on the Rights of the Child [Internet]. 2020 [cited 2020 Dec 14].

2. WHO. Children: improving survival and well-being [Internet]. 2020. Available from: https://www.who.int/news-room/fact-sheets/detail/children-reducing-mortality

3. United Nations Inter-agency Group for Child Mortality Estimation UI. Levels \& Trends in Child Mortality: Report 2019-Estimates developed by the UN Inter-agency Group for Child Mortality Estimation, United Nations Children's Fund, New York. New York, USA; 2019.

4. United Nations. DESA, Population Division, World Population Prospects [Internet]. 2019 [cited 2019 Dec 25]. Available from: http//population.un.org/wpp

5. UNICEF. Under-five mortality [Internet]. 2020 [cited 2020 Sep 8]. Available from: https://data.unicef.org/topic/child-survival/under-five-mortality/

6. Ahinkorah BO, Seidu A-A, Budu E, Armah-Ansah EK, Agbaglo E, Adu C, et al. Proximate, intermediate, and distal predictors of under-five mortality in Chad: analysis of the 2014-15 Chad demographic and health survey data. BMC Public Health. 2020;20(1873):1-12.

7. Akinyemi JO, Bamgboye EA, Ayeni O. Trends in neonatal mortality in Nigeria and effects of bio-demographic and maternal characteristics. BMC Pediatr. 2015;15(1):112. 
8. Alnsour J. Illegal Housing in Jordan. Jordan J Soc Sci. 2011;4(3):339-53.

9. Adebowale SA, Morakinyo OM, Ana GR. Housing materials as predictors of underfive mortality in Nigeria: evidence from 2013 demographic and health survey. BMC Pediatr [Internet]. 2017;17(1):30.

10. Clair A. Housing : an Under-Explored Influence on Children's Well-Being and Becoming. Child Indic Res. 2019;12:609-26.

11. NCB. Housing and the health of young children: policy and evidence briefing for the VCSE sector [Internet]. 2016. Available from: https://www.ncb.org.uk/sites/default/files/field/attachment/Housing and the Health of Young Children.pdf

12. Fullilove MT, Fullilove RE. What's housing got to do with it? Am J Public Health. 2000;90(2):183-4.

13. ICF International. Demographic and Health Survey: Sampling and Household Listing Manual. Calverton; 2012.

14. Croft TN, Marshall AMJ, Allen CK. Guide to DHS Statistics. 2018.

15. National Population Commission(NPC)[Nigeria], ICF International. Nigeria Demographic and Health Survey 2018. Abuja, Nigeria, And Rockville, Maryland, USA; 2019.

16. ICF International Inc. Uganda Demographic and Health Survey 2011. Kampala, Uganda: UBOS and Calverton, Maryland:; 2012.

17. Kenya National Bureau of Statistics, ICF International. Kenya Demographic Health Survey. 2015;

18. Morakinyo OM, Balogun FM, Fagbamigbe AF. Housing type and risk of malaria among under-five children in Nigeria: evidence from the malaria indicator survey. Malar J [Internet]. 2018;17(311):1-11.

19. Curtis SMK, Ghosh SK. A bayesian approach to multicollinearity and the simultaneous selection and clustering of predictors in linear regression. J Stat Theory Pract. 2011 Dec;5(4):715-35.

20. Oaxaca R. Male-female wage differentials in urban labor markets. Intl Econ Rev. 1973;14(4):693-709.

21. Hlavac M. oaxaca: Blinder-Oaxaca Decomposition in R. R package version 0.1.4. 2018. p. 1.

22. Blinder AS. Wage discrimination: Reduced form and structural estimates. J Hum Resour. 1973;8(4):436-55.

23. Fairlie RW, Robb AM. Why Are Black-Owned Businesses Less Successful than White-Owned Businesses? The Role of Families , Inheritances, and Business Human Capital. J Labor Econ. 2007;25(2):289-323.

24. Fairlie RW. Addressing Path Dependence and Incorporating Sample Weights in the Nonlinear Blinder-Oaxaca Decomposition Technique for Logit, Probit and Other Nonlinear Models. Stanford; 2017. (Stanford Institute for Economic Policy Research). Report No.: 17-013. 
25. Fairlie RW. An Extension of the Blinder-Oaxaca Decomposition Technique to Logit and Probit Models. Yale; 2003. Report No.: 873.

26. Fairlie RW. An extension of the Blinder-Oaxaca decomposition technique to logit and probit models. J Econ Soc Meas. 2005;30:305-16.

27. Jann B. Fairlie: Stata module to generate nonlinear decomposition of binary outcome differentials. 2006. p. 1.

28. Powers DA, Yoshioka H, Yun M. mvdemp: Multivariate Decomposition for nonlinear response models. Stata J. 2011;11(4):556-76.

29. Fairlie RW. The Absence of the African-American Owned Business: An Analysis of the Dynamics of Self-Employment. J Labor Econ. 1999;17(1):80-108.

30. Norman G, Pedley S, Takkouche B. Effects of sewerage on diarrhoea and enteric infections: a systematic review and meta-analysis. Lancet Infect Dis. 2010 Aug;10(8):536-44.

31. Monden CWS, Smits J. Mortality among twins and singletons in sub-Saharan Africa between 1995 and 2014: a pooled analysis of data from 90 Demographic and Health Surveys in 30 countries. Lancet Glob Heal [Internet]. 2017;5(7):e673-9.

32. Gebremedhin S. Multiple births in Sub-Saharan Africa: Epidemiology, postnatal survival, and growth pattern. Twin Res Hum Genet. 2015;18(1):100-7.

33. Bjerregaard-Andersen M, Lund N, Jepsen FS, Camala L, Gomes MA, Christensen K, et al. A prospective study of twinning and perinatal mortality in urban Guinea-Bissau. BMC Pregnancy Childbirth. 2012;12(140):1-12.

34. Bellizzi S, Sobel H, Betran AP, Temmerman M. Early neonatal mortality in twin pregnancy: Findings from 60 low- and middle-income countries. J Glob Health. 2018;8(1):1-14.

35. Ganchimeg T, Morisaki N, Vogel JP, Cecatti JG, Barrett J, Jayaratne K, et al. Mode and timing of twin delivery and perinatal outcomes in low- and middle-income countries: a secondary analysis of the WHO Multicountry Survey on Maternal and Newborn Health. BJOG. 2014;121 Suppl:89-100.

36. Nasr NA, Al-mekhlafi HM, Ahmed A, Roslan MA, Bulgiba A. Towards an effective control programme of soil-transmitted helminth infections among Orang Asli in rural Malaysia . Part 1 : Prevalence and associated key factors. Parasit Vectors. 2013;6(27):1-12.

37. Fagbamigbe AF, Morakinyo OM, Abatta E. Analysis of Regional Variations in Influence of Household and Environmental Characteristics on Prevalence of Diarrhoea among Under-Five Children in Nigeria. Ann Med Heal Sci Res. 2017;7(119130):119-30.

38. Morakinyo OM, Adebowale SA, Oloruntoba EO. Wealth status and sex differential of household head: implication for source of drinking water in Nigeria. Arch Public Health. 2015;73:58.

39. Kitur U, Adair T, Riley I, Lopez AD. Estimating the pattern of causes of death in Papua New Guinea. BMC Public Health. 2019;19(1322):1-12. 
40. NSO NSO. The National Population and Housing Census for Papua New Guinea for 2011. Port Moresby: NSO. 2011.

41. Wangi T, Wangi BT, Ezebilo E. Housing allowance for public servants in papua new guinea: Spolight. 2017;10(3):1-4.

42. Ezebilo E, Hamago L, Yala C. Assessment of Market Prices for Residential Properties in Port Moresby: Do Location and Property Type Matter? Port Moresby, Papua New Guinea; 2016.

43. Kitur U, Adair T, Lopez AD. Estimating Adult Mortality in Papua New Guinea, 2011. Popul Health Metr. 2019;17(4):1-14.

44. WHO. World malaria report 2019 [Internet]. WHO Regional Office for Africa. 2019. 1-185 p. Available from: https://www.who.int/news-room/fact-sheets/detail/malaria

45. Fakunle AG, Ana GR, Olaiya MT. Housing quality and risk of acute respiratory infections among hospitalized children under five in Ibadan, Nigeria Adekunle G Fakunle. Indoor Built Environ. 2016;25(8):1-12.

46. Akinyemi JO, Morakinyo OM. Household environment and symptoms of childhood acute respiratory tract infections in Nigeria , 2003 - 2013 : a decade of progress and stagnation. BMC Infect Dis. 2018;18(296):1-12.

47. Bado AR, Susuman AS. Women's education and health inequalities in under-five mortality in selected sub-saharan African countries, 1990-2015. PLoS One. 2016;11(7):e059186.

48. Yaya S, Uthman OA, Amouzou A, Ekholuenetale M, Bishwajit G. Inequalities in maternal health care utilization in Benin: A population based cross-sectional study. BMC Pregnancy Childbirth. 2018;18(1):1-9.

49. Yaya S, Bishwajit G, Okonofua F, Uthman OA. Under five mortality patterns and associated maternal risk factors in sub-Saharan Africa: A multi-country analysis. PLoS One. 2018;13(10):1-14.

50. WHO. More women and children survive today than ever before - UN report. 2019.

51. Yakubu I, Akaateba MA, Akanbang BAA. A study of housing conditions and characteristics in the Tamale Metropolitan Area, Ghana. Habitat Int [Internet]. 2014;44:394-402. Available from: http://dx.doi.org/10.1016/j.habitatint.2014.08.003

52. Yaya S, Bishwajit G, Ekholuenetale M, Shah V. Inadequate utilization of prenatal care services, socioeconomic status, and educational attainment are associated with low birth weight in Zimbabwe. Front Public Heal. 2017;5(MAR):1-7.

53. Adebowale AS, Yusuf BO, Fagbamigbe AF. Survival probability and predictors for woman experience childhood death in Nigeria: Analysis of north-south differentials. BMC Public Health [Internet]. 2012;12(430):1-12. Available from: ???

54. Govender T, Barnes JM, Pieper CH. Housing conditions, sanitation status and associated health risks in selected subsidized low-cost housing settlements in Cape Town, South Africa. Habitat Int [Internet]. 2011;35(2):335-42. Available from: http://dx.doi.org/10.1016/j.habitatint.2010.11.001

55. Lelkes O, Solyomi E. Housing quality deficiencies and the link to income in the EU. 
Vienna: European Centre for Social Welfare Policy and Research. 2010.

56. Eggleston PA, Arruda LK. Ecology and elimination of cockroaches and allergens in the home. J Allergy Clin Immunol. 2001;107(3 SUPPL.):422-9.

57. Ezeh OK, Agho KE, Dibley MJ, Hall JJ, Page AN. Risk factors for postneonatal, infant, child and under-5 mortality in Nigeria: a pooled cross-sectional analysis. BMJ Open [Internet]. 2015;5(3):e006779. Available from: http://www.ncbi.nlm.nih.gov/pubmed/25818271\%5Cnhttp://www.pubmedcentral.nih.g ov/articlerender.fcgi?artid=PMC4386230

58. Izugbara $\mathrm{C}$. Whose child is dying? Household characteristics and under-5 mortality in Nigeria. SAJCH South African J Child Heal. 2014;8(1):16-22.

59. Naz S, Page A, Agho KE. Household air pollution from use of cooking fuel and underfive mortality: The role of breastfeeding status and kitchen location in Pakistan. PLoS One. 2017;12(3):1-14.

60. Thomas P, Zelikoff J. Air pollutants: modulators of pulmonary host resistance against infection. Air pollut. Holgate S, Samet J, Koren H, Maynard R, editors. San Diego: Academic Press; 1999. 357-380 p.

61. Samet JM, Utell MJ. The risk of nitrogen dioxide: what have we learned from epidemiological and clinical studies? Toxicol Ind Health. 1990;6(2):247-62.

62. Naz S, Page A, Agho KE. Household air pollution and under-five mortality in India (1992 - 2006). Environ Heal. 2016;15(54):1-11.

63. Aziz FAA, Ahmad NA, Aznuddin M, Razak A, Omar M, Kasim NM, et al. Prevalence of and factors associated with diarrhoeal diseases among children under five in Malaysia : a cross-sectional study 2016. BMC Public Health [Internet]. 2018;18(1363):1-8.

64. Melese B, Paulos W, Astawesegn FH, Gelgelu TB. Prevalence of diarrheal diseases and associated factors among under-five children in Dale District, Sidama zone, Southern Ethiopia: A cross-sectional study. BMC Public Health. 2019;19(1):1-10.

65. Bitew BD, Woldu W, Gizaw Z. Childhood diarrheal morbidity and sanitation predictors in a nomadic community. Ital J Pediatr. 2017;43(1):1-8.

66. Malderen C Van, Amouzou A, Barros AJD, Masquelier B, Oyen H Van, Speybroeck N. Socioeconomic factors contributing to under-five mortality in sub-Saharan Africa: a decomposition analysis. BMC Public Health. 2019;19(760):1-19.

67. Khan JR, Awan N. A comprehensive analysis on child mortality and its determinants in Bangladesh using frailty models. Arch public Heal. 2017;75(58):1-10. 
1 Table 1: Distribution of sample characteristics by countries, regions and prevalence of under-

2 five deaths in LMIC by the quality of housing material, 2010-2018.

\begin{tabular}{|c|c|c|c|c|c|c|c|}
\hline \multirow[b]{2}{*}{ Country } & \multirow{2}{*}{$\begin{array}{l}\text { Survey } \\
\text { Year }\end{array}$} & \multirow[b]{2}{*}{ Sample } & \multirow{2}{*}{$\begin{array}{c}\text { Number of } \\
\text { Neighbourhoods }\end{array}$} & \multirow[t]{2}{*}{$\begin{array}{c}\text { UHM } \\
(\%)\end{array}$} & \multicolumn{3}{|c|}{$\begin{array}{l}\text { Under-5 Deaths per } 1000 \\
\text { livebirth }\end{array}$} \\
\hline & & & & & Overall & UHM & IHM \\
\hline Overall & & 798,796 & 59791 & 58.8 & 53 & $* 61$ & 41 \\
\hline Eastern Africa & & 107,839 & 6163 & 81.5 & 52 & $* 54$ & 45 \\
\hline Burundi & 2011 & 13,134 & 554 & 90.3 & 59 & $* 60$ & 41 \\
\hline Comoros & 2012 & 3,129 & 250 & 57.0 & 42 & 44 & 40 \\
\hline Ethiopia & 2016 & 10,508 & 635 & 97.6 & 55 & 56 & 32 \\
\hline Kenya & 2014 & 20,464 & 1544 & 71.2 & 44 & $* 46$ & 39 \\
\hline Malawi & 2016 & 17,159 & 845 & 82.4 & 49 & 49 & 49 \\
\hline Mozambique & 2011 & 10,950 & 598 & 85.1 & 74 & $* 76$ & 62 \\
\hline Rwanda & 2014 & 7,735 & 487 & 92.3 & 38 & 38 & 38 \\
\hline Tanzania & 2015 & 9,736 & 575 & 79.5 & 53 & 54 & 48 \\
\hline Uganda & 2016 & 15,024 & 675 & 72.3 & 50 & 51 & 47 \\
\hline Middle Africa & & 74,834 & 2851 & 78.1 & 70 & $* 76$ & 50 \\
\hline Angola & 2016 & 14,177 & 615 & 60.7 & 51 & $* 60$ & 38 \\
\hline Cameroon & 2018 & 9,211 & 404 & 61.3 & 61 & $* 65$ & 55 \\
\hline Chad & 2015 & 18,359 & 620 & 95.3 & 98 & 99 & 83 \\
\hline Congo & 2012 & 8,858 & 366 & 52.9 & 50 & 52 & 48 \\
\hline Congo DR & 2014 & 18,455 & 529 & 88.6 & 75 & $* 77$ & 59 \\
\hline Gabon & 2012 & 5,774 & 317 & 95.0 & 53 & 53 & 46 \\
\hline Southern Africa & & 26,797 & 2447 & 51.1 & 50 & 51 & 49 \\
\hline Lesotho & 2014 & 2,896 & 370 & 50.1 & 69 & 64 & 74 \\
\hline Namibia & 2013 & 4,902 & 517 & 65.3 & 44 & 47 & 38 \\
\hline South Africa & 2016 & 3,397 & 643 & 33.1 & 36 & $* 55$ & 26 \\
\hline Zambia & 2018 & 9,733 & 531 & 63.5 & 49 & 46 & 53 \\
\hline Zimbabwe & 2015 & 5,869 & 386 & 31.3 & 57 & 63 & 54 \\
\hline Western Africa & & 145,850 & 6021 & 61.4 & 81 & $* 91$ & 64 \\
\hline Benin & 2018 & 13,349 & 551 & 52.7 & 70 & $* 78$ & 61 \\
\hline Burkina Faso & 2010 & 14,887 & 569 & 85.4 & 89 & $* 95$ & 54 \\
\hline Cote d'Ivoire & 2013 & 7,585 & 344 & 42.5 & 82 & $* 93$ & 75 \\
\hline Gambia & 2013 & 7,961 & 278 & 55.5 & 41 & 40 & 42 \\
\hline Ghana & 2014 & 5,757 & 416 & 48.0 & 47 & 48 & 46 \\
\hline Guinea & 2018 & 7,839 & 396 & 50.2 & 87 & $* 106$ & 68 \\
\hline Liberia & 2013 & 7,438 & 315 & 64.8 & 70 & 68 & 73 \\
\hline Mali & 2018 & 9,883 & 344 & 77.6 & 72 & $* 82$ & 36 \\
\hline Niger & 2012 & 12,511 & 475 & 94.5 & 81 & $* 83$ & 48 \\
\hline Nigeria & 2018 & 33,480 & 1370 & 51.0 & 97 & $* 120$ & 73 \\
\hline Senegal & 2018 & 6,492 & 208 & 19.8 & 39 & $* 52$ & 36 \\
\hline Sierra Leone & 2013 & 11,842 & 432 & 69.5 & 114 & 111 & 119 \\
\hline Togo & 2013 & 6,826 & 323 & 57.0 & 62 & $* 75$ & 46 \\
\hline Central Asia & & 10,146 & 652 & 36.0 & 29 & 32 & 27 \\
\hline Kyrgyz Rep & 2012 & 4,135 & 300 & 23.7 & 26 & 33 & 25 \\
\hline Tajikistan & 2017 & 6,011 & 352 & 43.5 & 30 & 32 & 28 \\
\hline South-Eastern Asia & & 17,529 & 1834 & 62.9 & 26 & $* 30$ & 21 \\
\hline Cambodia & 2014 & 7,081 & 604 & 85.7 & 29 & $* 32$ & 10 \\
\hline Philippines & 2017 & 10,448 & 1230 & 46.4 & 24 & 26 & 23 \\
\hline Southern Asia & & 322,711 & 31390 & 48.7 & 44 & $* 52$ & 36 \\
\hline Afghanistan & 2015 & 32,398 & 945 & 91.2 & 47 & $* 48$ & 35 \\
\hline Bangladesh & 2014 & 7,214 & 552 & 69.1 & 41 & $* 45$ & 30 \\
\hline India & 2016 & 245,866 & 26848 & 41.3 & 44 & $* 55$ & 37 \\
\hline Indonesia & 2017 & 17,181 & 1894 & 54.6 & 27 & 25 & 28 \\
\hline Maldives & 2016 & 3,082 & 260 & 8.0 & 18 & 14 & 19 \\
\hline Nepal & 2016 & 4,674 & 352 & 62.8 & 33 & 35 & 30 \\
\hline Pakistan & 2018 & 12,296 & 539 & 66.4 & 66 & $* 74$ & 51 \\
\hline Western Asia & & 27,617 & 1986 & 26.8 & 33 & $* 45$ & 28 \\
\hline Armenia & 2016 & 1,711 & 305 & 7.8 & 05 & 05 & 05 \\
\hline
\end{tabular}




\begin{tabular}{|l|c|c|c|c|r|c|c|}
\hline Jordan & 2017 & 10,145 & 918 & 3.6 & 18 & 11 & 18 \\
\hline Yemen & 2013 & 15,761 & 763 & 42.4 & 45 & 47 & 43 \\
\hline Central America & & 22,747 & 1948 & 60.4 & 28 & $* 32$ & 22 \\
\hline Guatemala & 2014 & 12,252 & 845 & 50.8 & 31 & $* 39$ & 23 \\
\hline Honduras & 2011 & 10,495 & 1103 & 72.4 & 25 & 27 & 21 \\
\hline South America & & 9,022 & 1318 & 45.9 & 17 & $* 21$ & 14 \\
\hline Peru & 2012 & 9,022 & 1318 & 45.9 & 17 & $* 21$ & 14 \\
\hline Southern Europe & & 2,722 & 647 & 2.4 & 4 & 3 & 4 \\
\hline Albania & 2018 & 2,722 & 647 & 2.4 & 4 & 3 & 4 \\
\hline Caribbean & & 21,755 & 1796 & 55.6 & 45 & $* 50$ & 39 \\
\hline Dominican Rep & 2013 & 3,549 & 491 & 11.4 & 28 & $* 51$ & 26 \\
\hline Haiti & 2016 & 6,378 & 438 & 45.7 & 67 & 73 & 62 \\
\hline Myanmar & 2015 & 4,684 & 419 & 87.2 & 44 & $* 46$ & 28 \\
\hline Timor Leste & 2016 & 7,144 & 448 & 67.1 & 37 & $* 41$ & 28 \\
\hline Oceania & & 9,227 & 738 & 99.2 & 40 & 40 & 23 \\
\hline Papua NG & 2016 & 9,227 & 738 & 99.2 & 40 & 40 & 23 \\
\hline Total & & 798,796 & 59791 & 58.8 & 53 & $* 61$ & 41 \\
\hline
\end{tabular}

1

*significant at $5 \%$ test of equality of proportions

2

3

4

5

6

7

8

9

10

11

12

13

14

15

16

17

18

19

20

21

22 
1 Table 2: Summary of pooled background characteristics of the studied children and prevalence 2 of under-five deaths in LMIC by the quality of housing material, 2010-2018

\begin{tabular}{|c|c|c|c|c|c|c|}
\hline \multirow[b]{2}{*}{ Characteristics } & \multirow[b]{2}{*}{ sample } & \multirow[b]{2}{*}{$\%$} & \multirow{2}{*}{$\begin{array}{l}\text { UHM } \\
(\%)\end{array}$} & \multicolumn{3}{|c|}{ Under-5 Deaths per 1000 livebirth } \\
\hline & & & & Overall & UHM & $\mathrm{IHM}$ \\
\hline \multicolumn{7}{|l|}{ Maternal Current Age } \\
\hline $15-24$ & 233,276 & 29.2 & 59.7 & 54 & 62 & 43 \\
\hline $25-34$ & 413,113 & 51.7 & 56.2 & 48 & 57 & 37 \\
\hline $35-49$ & 152,407 & 19.1 & 64.5 & 62 & 69 & 49 \\
\hline Maternal Highest Education & & 0.0 & & & & \\
\hline No Education & 283,668 & 35.5 & 75.8 & 70 & 73 & 59 \\
\hline Primary & 207,148 & 25.9 & 70.1 & 55 & 57 & 50 \\
\hline Secondary+ & 307,980 & 38.6 & 36.4 & 36 & 43 & 32 \\
\hline Media & & 0.0 & & & & \\
\hline No & 332,556 & 41.7 & 78.2 & 66 & 68 & 59 \\
\hline Yes & 465,573 & 58.3 & 45.8 & 44 & 53 & 36 \\
\hline Maternal Employment & & 0.0 & & & & \\
\hline Employed & 306,061 & 54.0 & 67.5 & 63 & 68 & 51 \\
\hline Unemployed & 260,867 & 46.0 & 61.3 & 46 & 53 & 35 \\
\hline Paternal Employment & & 0.0 & & & & \\
\hline Employed & 512,803 & 95.7 & 64.9 & 56 & 63 & 43 \\
\hline Unemployed & 22,993 & 4.3 & 65.1 & 48 & 53 & 40 \\
\hline Marital status & & 0.0 & & & & \\
\hline Never married & 25,286 & 3.2 & 55.7 & 54 & 57 & 49 \\
\hline Currently married & 738,686 & 92.5 & 58.6 & 52 & 61 & 40 \\
\hline Formerly & 34,822 & 4.4 & 65.2 & 66 & 70 & 58 \\
\hline Sex of household head & & 0.0 & & & & \\
\hline Male & 670,970 & 84.0 & 58.9 & 53 & 61 & 41 \\
\hline Female & 127,826 & 16.0 & 58.1 & 52 & 58 & 42 \\
\hline Wealth index combined & & 0.0 & & & & \\
\hline Poorest & 206,972 & 25.9 & 89.8 & 64 & 65 & 49 \\
\hline Poorer & 180,011 & 22.5 & 74 & 59 & 63 & 49 \\
\hline Middle & 158,224 & 19.8 & 54.6 & 52 & 58 & 45 \\
\hline Richer & 138,947 & 17.4 & 38.2 & 46 & 55 & 41 \\
\hline Richest & 114,642 & 14.4 & 21.6 & 36 & 46 & 33 \\
\hline Covered by health insurance & & 0.0 & & & & \\
\hline No & 635,801 & 87.8 & 60.4 & 56 & 64 & 44 \\
\hline Yes & 88,596 & 12.2 & 41.3 & 34 & 41 & 29 \\
\hline Child is twin & & 0.0 & & & & \\
\hline Single birth & 777,993 & 97.4 & 58.8 & 49 & 56 & 38 \\
\hline Multiple & 20,803 & 2.6 & 60.7 & 203 & 233 & 158 \\
\hline Sex of child & & 0.0 & & & & \\
\hline Female & 389,073 & 48.7 & 59.2 & 49 & 56 & 38 \\
\hline Male & 409,723 & 51.3 & 58.5 & 56 & 65 & 44 \\
\hline Weight at birth & & 0.0 & & & & \\
\hline Average+ & 633,173 & 84.0 & 57.7 & 45 & 54 & 34 \\
\hline Small & 87,302 & 11.6 & 62.4 & 68 & 76 & 53 \\
\hline Very small & 33,169 & 4.4 & 66.8 & 116 & 113 & 123 \\
\hline \multicolumn{7}{|l|}{ Birth order } \\
\hline 1 & 219,586 & 27.5 & 49.9 & 50 & 62 & 38 \\
\hline 2 & 189,166 & 23.7 & 51.5 & 42 & 50 & 33 \\
\hline 3 & 129,778 & 16.2 & 59.2 & 48 & 53 & 40 \\
\hline $4+$ & 260,266 & 32.6 & 72.2 & 66 & 70 & 58 \\
\hline \multicolumn{7}{|l|}{ Birth interval } \\
\hline 1st Birth & 219,591 & 27.6 & 49.9 & 50 & 62 & 38 \\
\hline$<36$ months & 316,485 & 39.7 & 65.4 & 65 & 73 & 49 \\
\hline $36+$ months & 260,722 & 32.7 & 58.8 & 39 & 42 & 34 \\
\hline \multicolumn{7}{|l|}{ Drinking water } \\
\hline Unimproved sources & 186,576 & 23.4 & 80.8 & 67 & 70 & 54 \\
\hline Improved source & 612,220 & 76.6 & 52.8 & 49 & 57 & 40 \\
\hline
\end{tabular}




\begin{tabular}{|l|r|r|r|r|r|r|}
\hline Toilet type & & & & & & \\
\hline Unimproved sources & 410,192 & 51.4 & 77.1 & 63 & 66 & 54 \\
\hline Improved source & 388,378 & 48.6 & 40.2 & 42 & 51 & 36 \\
\hline Cooking fuel & & & & & & \\
\hline Unclean/biomass & 617,796 & 77.4 & 70.4 & 60 & 64 & 52 \\
\hline Clean fuel & 180,324 & 22.6 & 24.6 & 30 & 36 & 28 \\
\hline Place Of Residence & & & & & & \\
\hline Urban & 235,866 & 29.5 & 32.5 & 42 & 52 & 37 \\
\hline Rural & 562,930 & 70.5 & 70.9 & 58 & 63 & 46 \\
\hline Community SES Disadvantage & & & & & & \\
\hline Least & 160,002 & 20.1 & 27.7 & 34 & 43 & 30 \\
\hline 2 & 159,515 & 20.0 & 43.6 & 47 & 53 & 42 \\
\hline 3 & 159,642 & 20.0 & 71.1 & 57 & 61 & 48 \\
\hline 4 & 159,251 & 20.0 & 74.5 & 63 & 67 & 49 \\
\hline Highest & 158,401 & 19.9 & 78.8 & 63 & 67 & 53 \\
\hline Total & 796,672 & 100.0 & 58.8 & 53 & 61 & 41 \\
\hline
\end{tabular}

1

2

3

4

5

6

7

8

9

10

11

12

13

14

15

16

17

18

19

20

21

22 
2

3 Figure 1: Distribution of under-five mortality rate worldwide

$4 \quad$ Figure 2a \& b: Spatial distribution of under-five deaths among children in houses with

5 improved housing materials and houses with unimproved housing materials poor and non-

6 poor households in the LMIC studied

7 Figure 3: Forest plot of the risk difference in the prevalence of under-five deaths by the

8 improvement of housing materials in LMIC

$9 \quad$ Figure 4: Risk difference between children from houses with improved and unimproved

10 housing materials in the prevalence of under-five deaths by countries in LMIC

11 Figure 5: Scatter plot of rate of under-five deaths and risk difference between children from

12 houses with improved and unimproved housing materials in LMIC

13 Figure 6: Contributions of differences in the distribution 'compositional effect' of the 14 determinants of under-five deaths to the total gap between children from houses with improved 15 and unimproved housing materials among countries with pro-rural inequality 


\section{Figures}

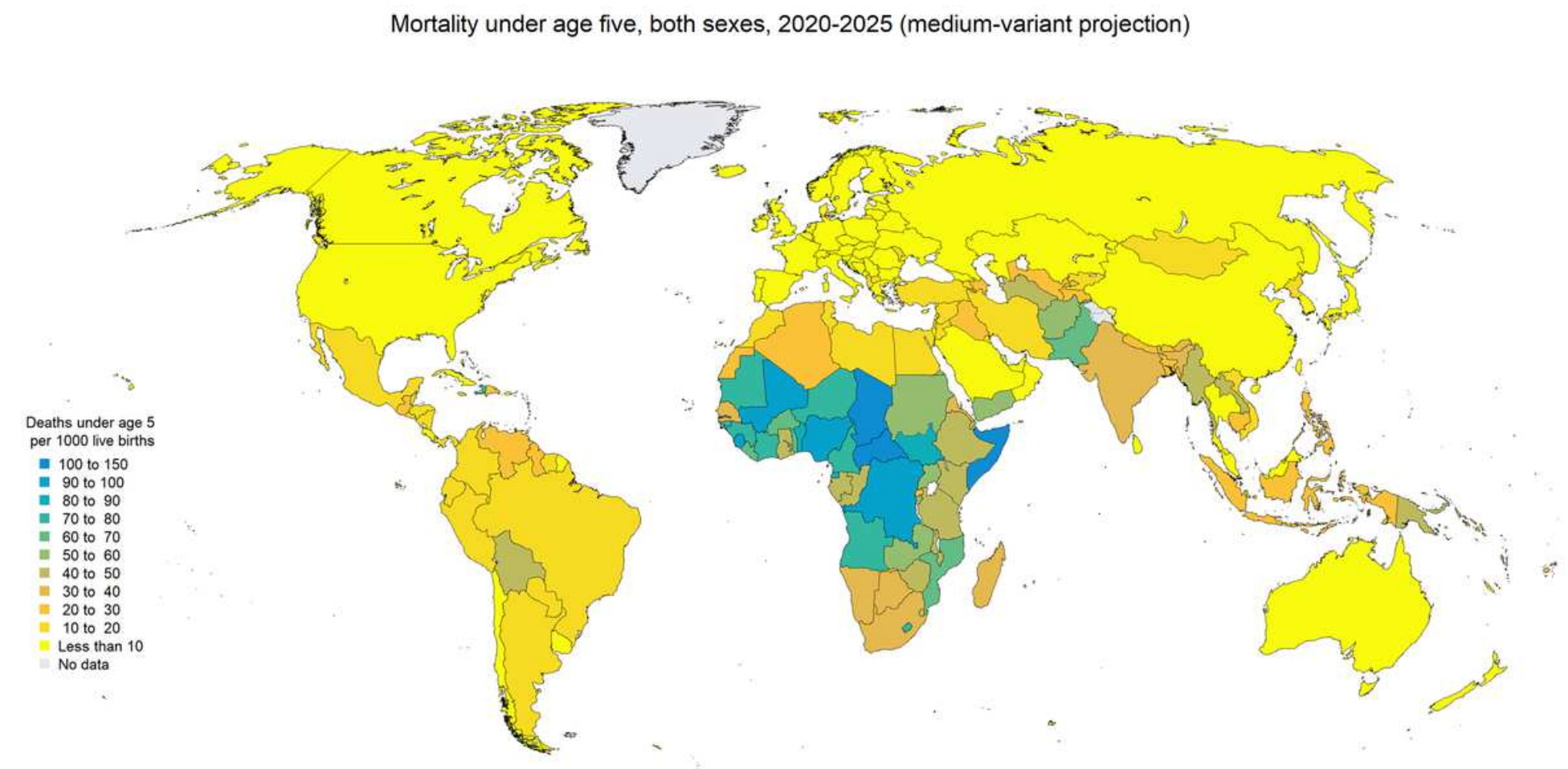

Jnited Nations, DESA, Population Division. Licensed under Creative Commons license CC BY 3.0160

\section{Figure 1}

Distribution of under-five mortality rate worldwide Note: The designations employed and the presentation of the material on this map do not imply the expression of any opinion whatsoever on the part of Research Square concerning the legal status of any country, territory, city or area or of its authorities, or concerning the delimitation of its frontiers or boundaries. This map has been provided by the authors. 

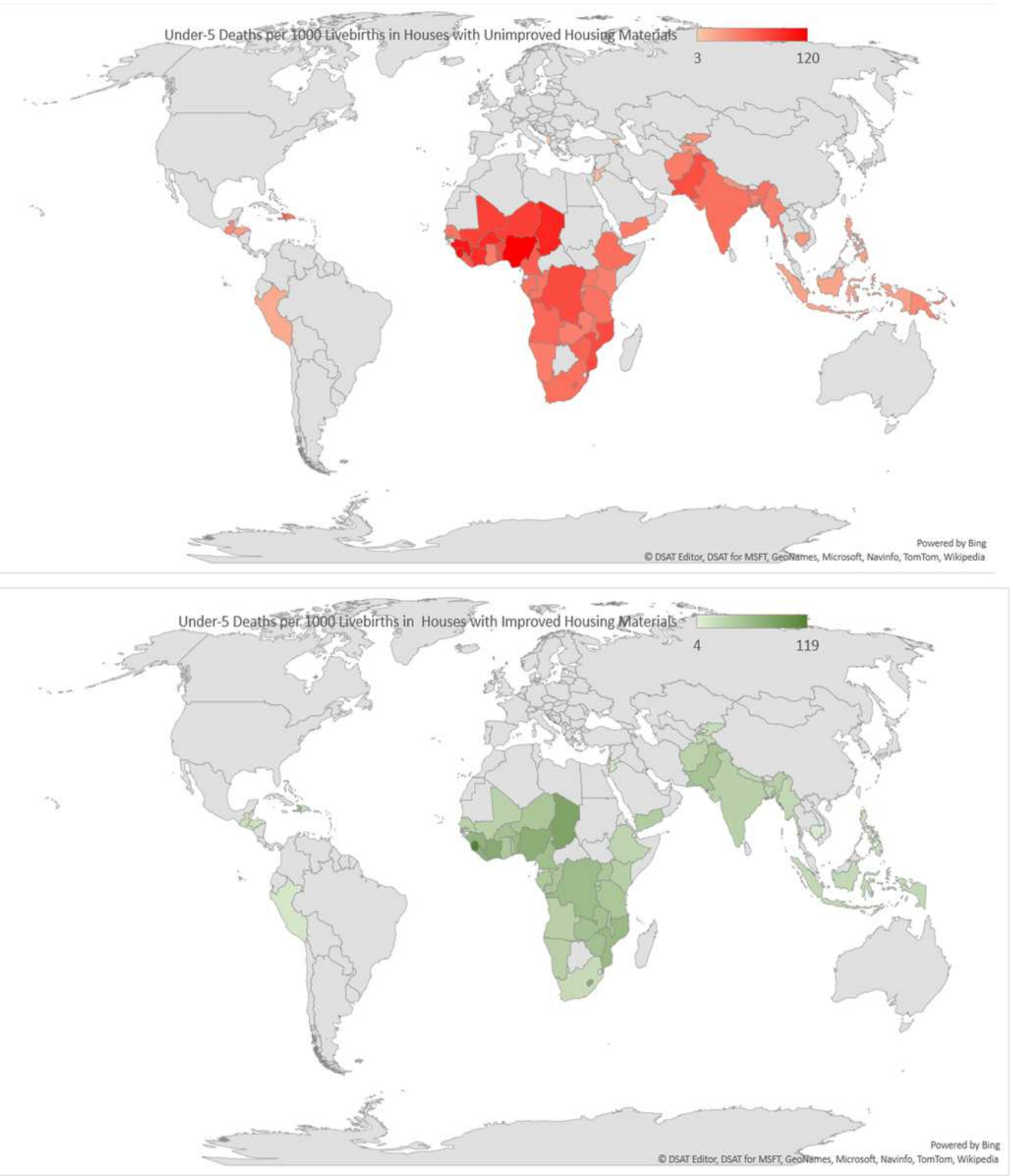

\section{Figure 2}

a \& b: Spatial distribution of under-five deaths among children in houses with improved housing materials and houses with unimproved housing materials poor and non-poor households in the LMIC studied Note: The designations employed and the presentation of the material on this map do not imply the expression of any opinion whatsoever on the part of Research Square concerning the legal status of 
any country, territory, city or area or of its authorities, or concerning the delimitation of its frontiers or boundaries. This map has been provided by the authors.

\begin{tabular}{|c|c|c|c|c|c|c|}
\hline Country & $\begin{array}{l}\text { Unimproved HM } \\
\% \text { Under-5 Death }\end{array}$ & $\begin{array}{l}\text { Improved HM } \\
\text { Under-5 Death(\%) }\end{array}$ & $\begin{array}{l}\text { Risk Difference } \\
\text { (events per } 100 \mathrm{obs} \text {.) }\end{array}$ & RD & \multicolumn{2}{|c|}{$95 \%-\mathrm{Cl}$ Weight } \\
\hline $\begin{array}{l}\text { Eastern Africa } \\
\text { Ethiopia, 2016 } \\
\text { Burundi, 2016 } \\
\text { Mozambique, } 2011 \\
\text { Kenya, 2014, } \\
\text { Tanzania, 2015 } \\
\text { Comoros, 2012 } \\
\text { Uganda, } 2016 \\
\text { Rwanda, 2014 } \\
\text { Malawi, 2016 }\end{array}$ & $\begin{array}{l}5.60 \\
6.00 \\
7.60 \\
4.60 \\
5.40 \\
4.40 \\
5.10 \\
3.80 \\
4.90\end{array}$ & $\begin{array}{l}3.20 \\
4.10 \\
6.20 \\
3.90 \\
4.80 \\
4.00 \\
4.70 \\
3.80 \\
4.90\end{array}$ & & $\begin{array}{r}2.51 \\
1.94 \\
1.38 \\
0.77 \\
0.61 \\
0.49 \\
0.38 \\
0.03 \\
-0.01\end{array}$ & 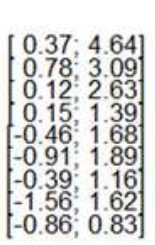 & $\begin{array}{l}1.2 \% \\
1.8 \% \\
1.7 \% \\
2.1 \% \\
1.9 \% \\
1.7 \% \\
2.0 \% \\
1.5 \% \\
2.0 \%\end{array}$ \\
\hline $\begin{array}{l}\text { Middle Africa } \\
\text { Angola, 2016 } \\
\text { CongoDR } 2014 \\
\text { Chad, 2015 } \\
\text { Cameroon, } 2018 \\
\text { Gabon, } 2012 \\
\text { Congo, } 2012\end{array}$ & $\begin{array}{l}6.00 \\
7.70 \\
9.90 \\
6.50 \\
5.30 \\
5.20\end{array}$ & $\begin{array}{l}3.80 \\
5.90 \\
8.30 \\
5.50 \\
4.60 \\
4.80\end{array}$ & & $\begin{array}{l}2.21 \\
1.70 \\
1.56 \\
1.07 \\
0.81 \\
0.33\end{array}$ & {$\left[\begin{array}{r}1.48 ; 2.95 \\
0.60 ; 2.80 \\
-0.33 ; 3.46 \\
0.10 ; 2.03 \\
-1.86 ; 3.48 \\
-0.64 ; 1.30\end{array}\right]$} & $\begin{array}{l}2.1 \% \\
1.8 \% \\
1.3 \% \\
1.9 \% \\
1.0 \% \\
1.9 \%\end{array}$ \\
\hline $\begin{array}{l}\text { Southern Africa } \\
\text { SouthAfrica, } 2016 \\
\text { Zimbabwe, } 2015 \\
\text { Namibia, } 2013 \\
\text { Zambia, } 2018 \\
\text { Lesotho, } 2014\end{array}$ & $\begin{array}{l}5.50 \\
6.30 \\
4.70 \\
4.60 \\
6.40\end{array}$ & $\begin{array}{l}2.60 \\
5.40 \\
3.80 \\
5.30 \\
7.40\end{array}$ & & $\begin{array}{r}2.88 \\
0.86 \\
0.82 \\
-0.71 \\
-1.01\end{array}$ & {$\left[\begin{array}{r}1.40 ; 4.36 \\
-0.41 ; 2.14 \\
-0.37 ; 2.02 \\
-1.62 ; 0.20 \\
-2.86 ; 0.84\end{array}\right]$} & $\begin{array}{l}1.6 \% \\
1.7 \% \\
1.8 \% \\
2.0 \% \\
1.4 \%\end{array}$ \\
\hline $\begin{array}{l}\text { Western Africa } \\
\text { Nigeria, } 2018 \\
\text { Mali, 2018 } \\
\text { BurkinaFaso, } 2010 \\
\text { Guinea } 2018 \\
\text { Niger, } 2012 \\
\text { Togo, } 2013 \\
\text { Cotedlvoire, } 2012 \\
\text { Benin, 2018 } \\
\text { Senegal, 2018 } \\
\text { Ghana, 2014 } \\
\text { Gambia, 2013 } \\
\text { Liberia, 2013 } \\
\text { SierraLeone, } 2013\end{array}$ & $\begin{array}{c}12.00 \\
8.20 \\
9.50 \\
10.60 \\
8.30 \\
7.50 \\
9.30 \\
7.80 \\
5.20 \\
4.80 \\
4.00 \\
6.80 \\
11.10\end{array}$ & $\begin{array}{l}7.30 \\
3.60 \\
5.40 \\
6.80 \\
4.80 \\
4.60 \\
7.50 \\
6.10 \\
3.60 \\
4.60 \\
4.20 \\
7.30 \\
11.90\end{array}$ & & $\begin{array}{r}4.65 \\
4.60 \\
4.07 \\
3.78 \\
3.37 \\
2.95 \\
1.82 \\
1.67 \\
1.62 \\
0.12 \\
-0.26 \\
-0.54 \\
-0.73\end{array}$ & 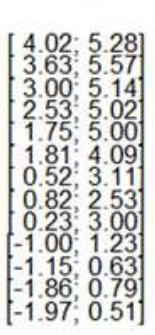 & $\begin{array}{l}2.1 \% \\
1.9 \% \\
1.9 \% \\
1.8 \% \\
1.5 \% \\
1.8 \% \\
1.7 \% \\
2.0 \% \\
1.7 \% \\
1.8 \% \\
2.0 \% \\
1.7 \% \\
1.8 \%\end{array}$ \\
\hline $\begin{array}{l}\text { Central Asia } \\
\text { KyrgyzRep } 2012 \\
\text { Tajikistan, } 2017\end{array}$ & $\begin{array}{l}3.30 \\
3.20\end{array}$ & $\begin{array}{l}2.50 \\
2.80\end{array}$ & & $\begin{array}{l}0.80 \\
0.34\end{array}$ & {$\left[\begin{array}{l}-0.48 ; 2.08 \\
-0.51 ; 1.19\end{array}\right]$} & $\begin{array}{l}1.7 \% \\
2.0 \%\end{array}$ \\
\hline $\begin{array}{l}\text { South-Eastern Asia } \\
\text { Cambodia, } 2014 \\
\text { Philippines, } 2017\end{array}$ & $\begin{array}{l}3.20 \\
2.60\end{array}$ & $\begin{array}{l}1.00 \\
2.30\end{array}$ & 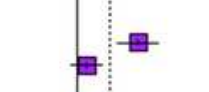 & $\begin{array}{l}2.27 \\
0.33\end{array}$ & {$\left[\begin{array}{r}1.52 ; 3.02 \\
-0.28 ; 0.94\end{array}\right]$} & $\begin{array}{l}2.1 \% \\
2.1 \%\end{array}$ \\
\hline $\begin{array}{l}\text { Southern Asia } \\
\text { Pakistan, } 2018 \\
\text { India, 2016 } \\
\text { Bangladesh, } 2014 \\
\text { Afghanistan, } 2015 \\
\text { Nepal, 2016 } \\
\text { Indonesia, } 2017 \\
\text { Maldives, } 2016\end{array}$ & $\begin{array}{l}7.40 \\
5.50 \\
4.50 \\
4.80 \\
3.50 \\
2.50 \\
1.40\end{array}$ & $\begin{array}{l}5.10 \\
3.70 \\
3.00 \\
3.50 \\
3.00 \\
2.80 \\
1.90\end{array}$ & & $\begin{array}{l}2.25 \\
1.84 \\
1.56 \\
1.26 \\
0.47 \\
-0.27 \\
-0.50\end{array}$ & {$\left[\begin{array}{r}1.28 ; 3.21 \\
1.66 ; 2.01 \\
0.66 ; 2.46 \\
0.53 ; 1.99 \\
-0.58 ; 1.51 \\
-0.77 ; 0.22 \\
-2.13 ; 1.12\end{array}\right]$} & $\begin{array}{l}1.9 \% \\
2.3 \% \\
2.0 \% \\
2.1 \% \\
1.9 \% \\
2.2 \% \\
1.5 \%\end{array}$ \\
\hline $\begin{array}{l}\text { Western Asia } \\
\text { Yemen, } 2013 \\
\text { Armenia } 2016 \\
\text { Jordan, } 2017\end{array}$ & $\begin{array}{l}4.70 \\
0.50 \\
1.10\end{array}$ & $\begin{array}{l}4.30 \\
0.50 \\
1.80\end{array}$ & & $\begin{array}{r}0.47 \\
0.25 \\
-0.88\end{array}$ & {$\left[\begin{array}{l}-0.19 ; 1.13 \\
-1.30 ; 1.81 \\
-1.94 ; 0.19\end{array}\right]$} & $\begin{array}{l}2.1 \% \\
1.6 \% \\
1.9 \%\end{array}$ \\
\hline $\begin{array}{l}\text { Central America } \\
\text { Guatemala, } 2014 \\
\text { Honduras, } 2011\end{array}$ & $\begin{array}{l}3.90 \\
2.70\end{array}$ & $\begin{array}{l}2.30 \\
2.10\end{array}$ & & $\begin{array}{l}1.57 \\
0.56\end{array}$ & {$\left[\begin{array}{r}0.96 ; 2.18 \\
-0.10 ; 1.21\end{array}\right]$} & $\begin{array}{l}2.1 \% \\
2.1 \%\end{array}$ \\
\hline $\begin{array}{l}\text { South America } \\
\text { Peru, } 2012\end{array}$ & 2.10 & 1.40 & 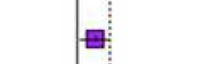 & 0.65 & {$[0.08 ; 1.23]$} & $2.1 \%$ \\
\hline $\begin{array}{l}\text { Southern Europe } \\
\text { Albania, } 2018\end{array}$ & 0.30 & 0.40 & & -0.45 & {$[-2.72 ; 1.83]$} & $1.1 \%$ \\
\hline $\begin{array}{l}\text { Caribbean } \\
\text { DominicanRep } 2013 \\
\text { Myanmar, 2015 } \\
\text { TimorLeste, } 2016 \\
\text { Haiti, 2016. }\end{array}$ & $\begin{array}{l}5.10 \\
4.60 \\
4.10 \\
7.30\end{array}$ & $\begin{array}{l}2.60 \\
2.80 \\
2.80 \\
6.20\end{array}$ & 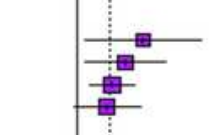 & $\begin{array}{l}2.47 \\
1.79 \\
1.28 \\
1.11\end{array}$ & 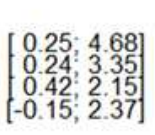 & $\begin{array}{l}1.2 \% \\
1.6 \% \\
2.0 \% \\
1.7 \%\end{array}$ \\
\hline $\begin{array}{l}\text { Oceania } \\
\text { PapuaNG, } 2016\end{array}$ & 4.00 & 2.30 & & 1.29 & {$[-2.47 ; 5.06]$} & $0.6 \%$ \\
\hline Random effects model & & & 1 & 1.19 & {$[0.84 ; 1.53]$} & $100.0 \%$ \\
\hline & & -4 & -2 & 6 & & \\
\hline
\end{tabular}

\section{Figure 3}

Forest plot of the risk difference in the prevalence of under-five deaths by the improvement of housing materials in LMIC 


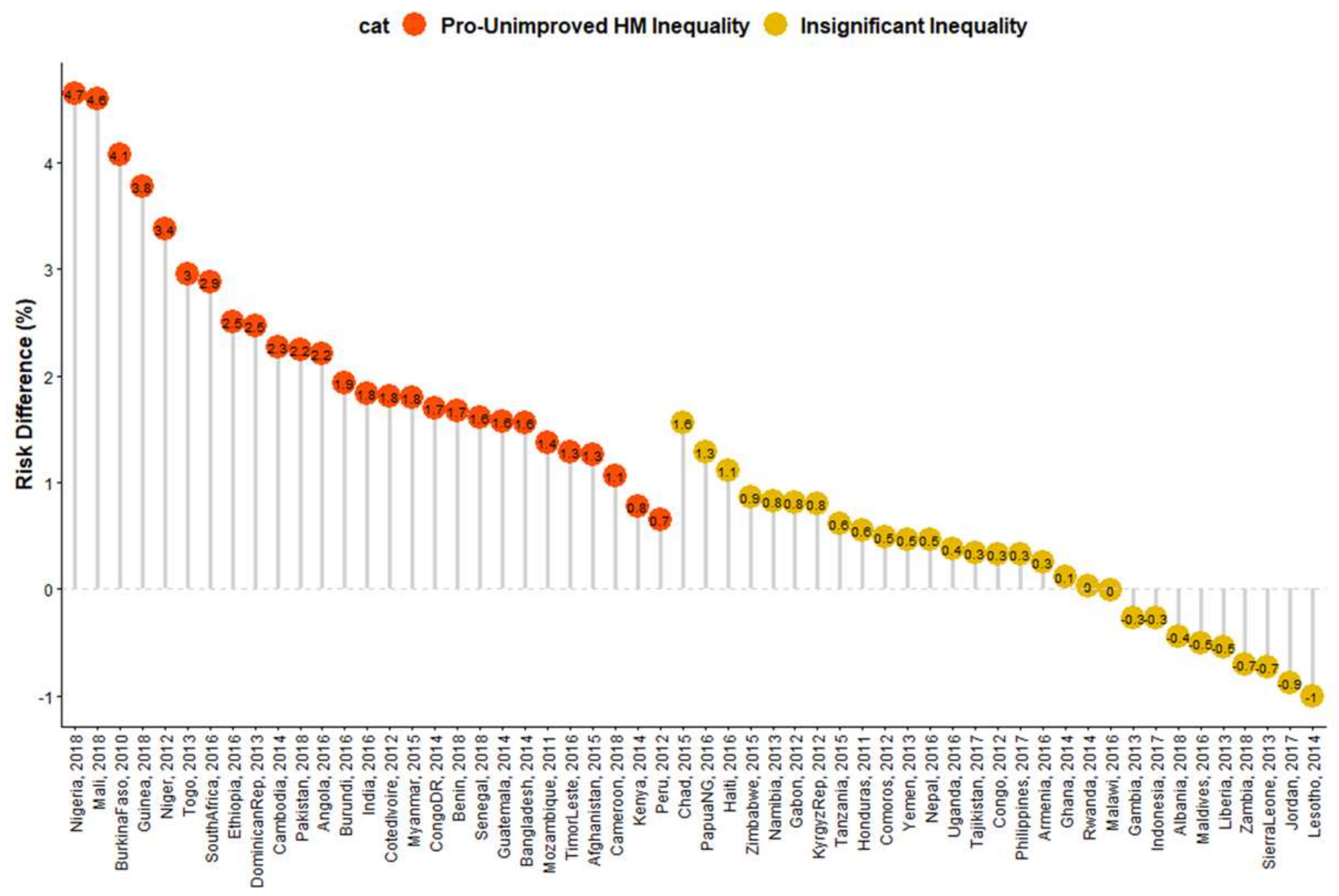

Figure 4

Risk difference between children from houses with improved and unimproved housing materials in the prevalence of under-five deaths by countries in LMIC 


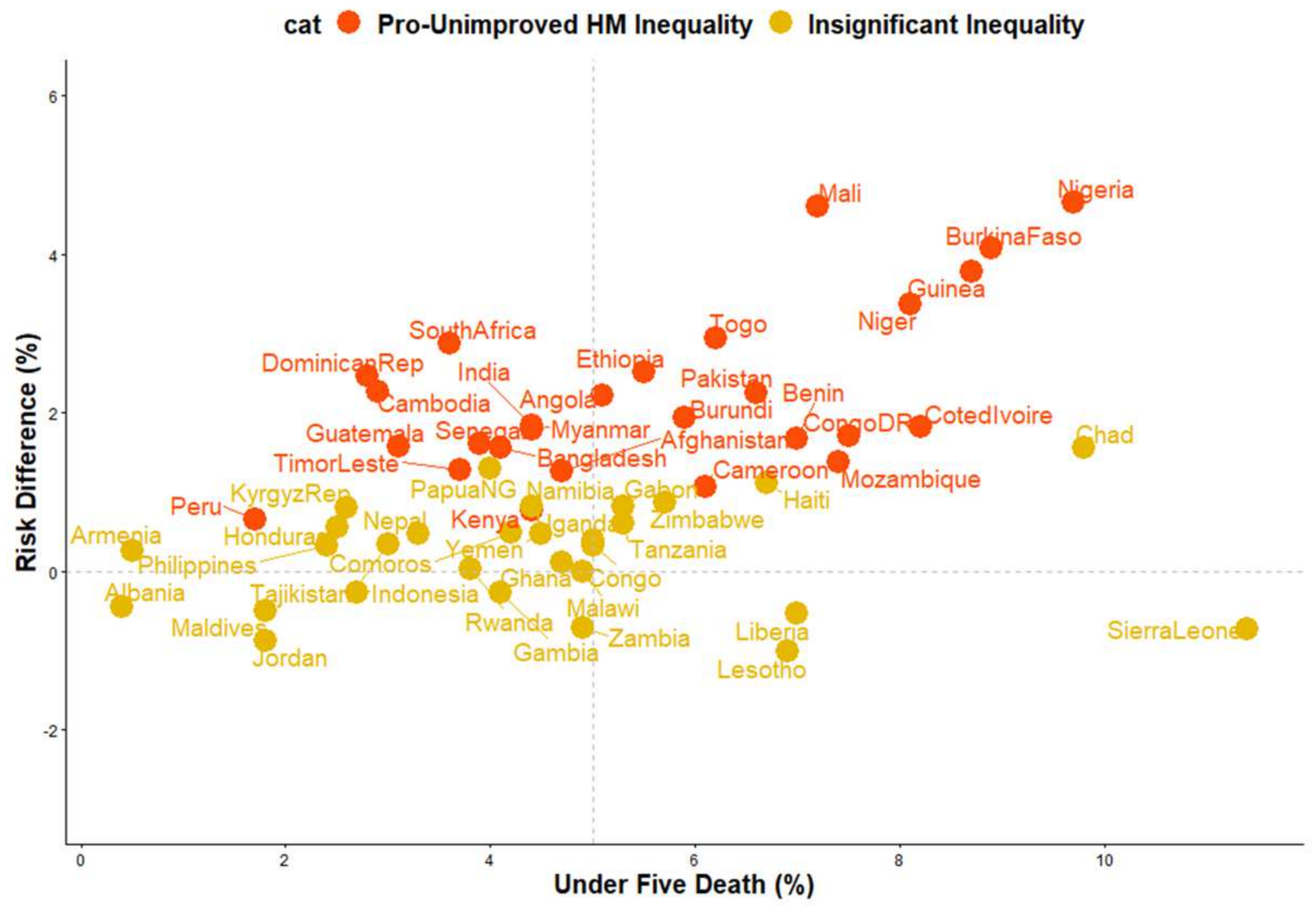

Figure 5

Scatter plot of rate of under-five deaths and risk difference between children from houses with improved and unimproved housing materials in LMIC 


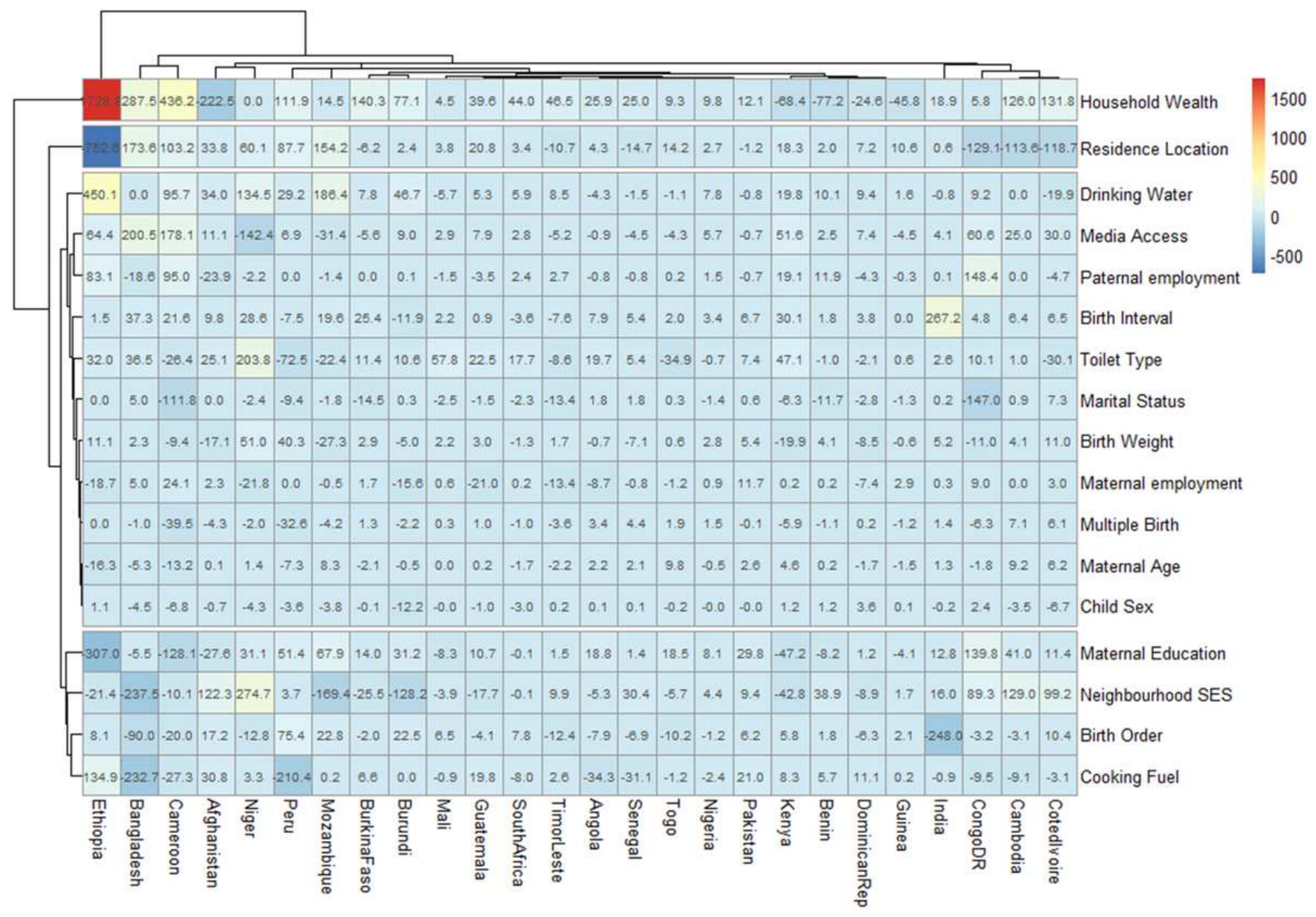

Figure 6

Contributions of differences in the distribution 'compositional effect' of the determinants of under-five deaths to the total gap between children from houses with improved and unimproved housing materials among countries with pro-rural inequality 